\title{
FOREIGN CURRENCY DERIVATIVE USE AND SHAREHOLDER VALUE
}

\author{
Yacine Belghitar ${ }^{\mathrm{a}}$, Ephraim Clark ${ }^{\mathrm{b}}$ and Salma Mefteh ${ }^{\mathrm{c}}$ \\ ${ }^{a}$ Cranfield School Management, Cranfield University, Bedford, MK43 0AL UK \\ phone: 44 (0)1234751122, email:yacine.belghitar@cranfield.ac.uk (corresponding author). \\ ${ }^{b}$ Middlesex Business School, Middlesex University, The Burroughs, Hendon London, NW4 \\ 4BT, UK and University de Lille Nord de France SKEMA, phone: 44 (0)20 8411 530, email: \\ e.clark@mdx.ac.uk
}

${ }^{c}$ ESSCA Business School, 1 rue Lakanal, 49003, Angers and Paris-Dauphine University, 75775 Paris, FRANCE, Phone: 33 0241734739, email: salma.mefteh@essca.fr

\begin{abstract}
This paper investigates the effect of foreign currency (FC) derivatives use on shareholder value. Exposures are broken down by currency, by whether the currency is appreciating or depreciating and by whether exposures are symmetric or asymmetric. We find that derivatives are effective in reducing overall FC exposure but there is no evidence of value creation through the application of a program that identifies and targets only loss causing exposures. We also find that FC derivatives use has no significant effect on firm value in the overall sample and when the sample is broken down by exposure type and derivative product.
\end{abstract}

Keywords: Foreign currency exposure, Asymmetric exposure, Foreign currency hedging, Derivatives, Firm value.

JEL Classification: F31; G32. 


\section{Introduction}

Exchange rate volatility and its associated effects on the profitability and value of multinational companies have attracted widespread attention in the wake of the post-war development of international trade, globalized financial markets, and flexible exchange rates. Motivated by the positive theory of corporate hedging developed by Smith and Stulz (1985) and a substantial literature on the foundations of currency risk exposure, which analyzes the parameters and transmission mechanisms that determine a firm's sensitivity to exchange rate movements, ${ }^{1}$ corporate use of derivatives to hedge this foreign currency (FC) exposure has become standard practice for modern firms with foreign operations or commercial interests. ${ }^{2}$ Because the conception and implementation of a derivatives based FC hedging strategy requires a commitment of financial, physical and human resources, it has also become a source of significant costs for the firm. However, the empirical evidence on whether FC derivatives use actually contributes anything to firm performance and shareholder value is mixed. For example, Allayannis and Weston (2001), Kim et al.(2006), Belghitar et al. (2008) and Clark and Judge (2009) find evidence that FC derivatives hedging does add to firm value. ${ }^{3}$ On the other hand, Bartram (2004) and Jin and Jorion (2006) find no value effects for FC derivative users. Hagelin et al. (2007) find that FC hedging that satisfies managerial self

\footnotetext{
${ }^{1}$ The elasticities and absorption approach to balance of payments theory emphasized the role of exchange rate fluctuations as a major source of macroeconomic uncertainty that can have a significant impact on individual firm value. For some of the original work see: Meade (1951), Alexander (1952 and 1959), Pearce (1961), Tsiang (1961), Gerakis (1964) and Caves and Johnson (1968). More recent research analyzes the parameters and transmission mechanisms that determine a firm's sensitivity to exchange rate movements and consistently confirms the relationship between exchange rate movements and firm value (e.g. Shapiro, 1975; Dumas, 1978; Hodder, 1982; Flood and Lessard, 1986; Booth and Rottenberg, 1990; Levi, 1994; Marston, 2001; Allayannis and Ihrig, 2001; and Bodnar et al., 2002).

${ }^{2}$ This is well documented in the corporate hedging literature. For US firms, there are studies such as Wysocki (1995), Géczy et al. (1997), Goldberg et al. (1998), Howton and Perfect (1998), Graham \& Rogers (2002), Allayannis and Ofek (2001). Studies of non-US firms include Berkman and Bradbury (1996) on New Zealand firms, Hagelin (2003) on Swedish firms and Pramborg (2005) on Swedish and Korean firms, Nguyen and Faff (2003) on Australian firms, and Heaney and Winata (2005) on Australian firms. The International Swaps and Derivatives Association (ISDA) 2003 derivative usage survey reports that today 92\% of the world's 500 largest companies representing a wide range of geographic regions and industry sectors use derivatives for risk management on a regular basis (http://www.isda.org/statistics/surveynewsrelease030903v2.html).

${ }^{3}$ Magee (2009) calls into question the positive statistical relation between FC hedging and value by showing that the positive, significant, statistical relationship between FC hedging and value disappears after controlling for the possibility that past levels of firm value affect current levels of foreign currency hedging.
} 
interest actually reduces firm value and Allayannis et al. (2009) find that the FC hedging premium is statistically significant and economically large only for firms that have strong internal and external corporate governance. Thus, the empirical status quo suggests that the jury is still out and the relationship between FC derivatives use and firm performance remains an open question.

This paper incorporates two important features of the FC paradigm that have not been explicitly considered in the extant literature and revists the relationship between derivatives use and shareholder value. ${ }^{4}$ First, it recognizes that the FC exposure of each firm can vary with respect to individual currencies and whether these currencies are appreciating or depreciating, depending on the specific portfolio of transactions in foreign currency of each firm, the FC exposure of its clients and suppliers, as well as that of its competitors. Second, it recognizes that derivatives use is just one part of a broader financial strategy that considers the type and level of financial risks, the availability of risk-management tools, and the operating environment of the firm. ${ }^{5}$ Besides derivatives, corporations employ pass-through, operational hedging, and foreign currency debt to manage financial risk (Bartram, Brown and Minton, 2009; Guay and Kothari, 2003; Kedia and Mozumdar, 2003). Derivatives themselves can be broken down into those with symmetric payoffs, such as forwards, futures and swaps, and those with asymmetric payoffs, such as options. This paper controls for the FC exposure of each firm broken down by currency, by whether the currency is appreciating or

\footnotetext{
${ }^{4}$ See Aretz and Bartram (2011) for a detailed and comprehensive overview and analysis of the theoretical arguments and the corresponding empirical evidence in the existing literature pertaining to corporate risk management as a lever for shareholder value creation.

${ }^{5}$ These corporate hedging activities seem to be quite effective based on an extensive literature that shows only weak evidence of the effect of unexpected exchange rate changes on stock returns. See, for example, Jorion (1990), Bodnar and Gentry (1993), Amihud (1994), Choi and Prasad (1995), He and Ng (1998), Miller and Reuer (1998), Griffin and Stulz, (2001), Hagelin and Prambourg (2004), Nguyen et al. (2007). When asymmetric reactions to currency movements are taken into consideration (e.g. Di Iorio and Faff, 2000; Krishnamoorthy, 2001; Koutmos and Martin, 2003, Oh and Lee, 2004, Muller and Verschoor, 2006a, and Clark and Mefteh, 2011) the percentage of significant FC exposures rises considerably but still remains relatively small. See Muller and Vershoor (2006b) for a comprehensive review of the literature.
} 
depreciating and by whether exposures are symmetric or asymmetric and tests the relationship between derivatives use and value creation.

The positive theories of risk management at the firm level in the presence of capital market imperfections argue that shareholder value can be increased through an overall reduction in exposure, which leads to a reduction of external claims on the cash stream flowing from the firm's assets. Such claims include taxes paid to government by the firm; bankruptcy costs (both direct and indirect) paid to accountants, lawyers and the firm's noninvestor stakeholders; and/or agency costs to align managerial interests with the interests of capital suppliers. ${ }^{6}$ However, there is growing evidence that FC exposure can be asymmetric with respect to appreciations and depreciations of a currency. ${ }^{7}$ Asymmetric exposures mean that gains due to appreciations (depreciations) of a currency are greater than losses due to depreciations (appreciations) or vice versa. Asymmetric exposures complicate the decision of whether or not to hedge and what type of derivative is most appropriate.

Consider, for example, a USD based company with a long position in euros (EUR). Other things being equal, an appreciation of the USD with respect to the EUR would cause a FC loss, while a depreciation would generate a FC gain. The basic choice is no hedge; hedge using a derivative with a symmetric payoff and no up-front cost like a forward or futures contract; and hedge using an option type derivative with an asymmetric payoff. If no hedge is undertaken, there is no exposure reduction but the costs associated with a derivatives transaction are saved. All FC exposure is eliminated with a forward/futures contract, but the drawback is that the firm loses out if the exchange rate moves in its favour. With an option type derivative the possibility of a loss is eliminated while the possibility of a gain is preserved. If the exchange rate moves against the firm, the option is exercised and the loss is avoided. If it moves in the firm's favour, the option expires worthless but the firm benefits

\footnotetext{
${ }^{6}$ See Aretz and Bartram (2011) for a comprehensive survey and analysis.

${ }^{7}$ See, for example, Choi and Prasad (1995), Di Iorio and Faff (2000), Krishnamoorthy (2001), Koutmos and Martin (2003), Oh and Lee (2004), Tai (2008) and Clark and Mefteh (2011).
} 
from the favourable move. The drawback to option type derivatives is their relatively high upfront cost. To make this strategy profitable, the move in the exchange rate (either way) has to be large enough to offset the cost of the option. In the absence of asymmetric exposures, the rule of thumb, then, is: a) if the exchange rate is expected to be stable or change in favour of the firm, don't hedge; b) if there is a high probability that the exchange rate will move against the firm, hedge with a derivative with a symmetric payoff; c) if there is a high probability that there will be a very large move in the exchange rate in either direction, hedge with a derivative with an asymmetric payoff.

Asymmetric exposures complicate the analysis and in many circumstances can, counter-intuitively, lead to less use of option type derivatives in particular or less use of any kind of derivative in general. Without going into too much detail two examples illustrate the point. Consider an exposure profile that is asymmetric in favour of the firm (the exposure that benefits the firm is larger than the exposure that hurts the firm) and there is no big difference in the probability of a move one way or the other, the best strategy could be no hedging at all, since on average gains would be larger than losses. Now consider a situation where there is a high probability that there will be a large move in the exchange rate in either direction and an exposure profile that is asymmetric against the firm (the exposure that hurts the firm is larger than the exposure that benefits it). If the exposure that benefits the firm is not large enough to justify the cost of an option type derivative, which would normally be appropriate if the exposures were symmetric, a zero cost derivative with a symmetric payoff would be more appropriate. Decisions with respect to situations such as these affect the cost of hedging, how exposure is reduced and the potential for shareholder value creation.

To summarize, there are two major avenues for value creation. The first is through a reduction in overall exposure that leads to a reduction in external claims on the firm's cash flows. The second is through the judicious application of a cost effective hedging program 
that can reduce or eliminate loss causing exposures with minimum interference with profitable exposures. The overall success of a derivatives based hedging program in creating shareholder value depends on whether or not the total gains outweigh the costs.

To explore these insights, this study looks at a French sample and breaks down overall FC exposure with respect to different currencies and different types of exposure that depend on whether the currency appreciates or depreciates. It then examines whether and how FC derivatives have affected the value of the firm. The major innovation of this paper is that it exploits the concept of asymmetry to distinguish between situations where FC derivatives use can and cannot make a positive contribution to firm performance. More specifically, it observes the signs of the exposures with respect to currency appreciations and depreciations to identify "good" exposures, those that increase returns and should not be hedged, and "bad" exposures, those that reduce returns and should be hedged. These exposures are further refined by controlling for correlations between the USD and non-USD currencies and by distinguishing between significant and non-significant asymmetric exposures.

The contribution of this paper takes several directions. The major contribution uses the detailed exposure breakdown to analyze whether derivatives use has been effective in creating shareholder value by exploiting "good" exposures as well as through overall exposure reduction. Our results provide strong evidence that derivatives are effective in reducing overall FC exposure but there is no statistical difference between "good" and "bad" exposures associated with currency appreciations (depreciations). This is evidence that the strategies driving FC derivatives use are not effectively creating shareholder value by distinguishing between the "good" and "bad" exposures. Interestingly, derivatives use has no statistically significant effect on the sub-sample of statistically significant asymmetric exposures even after controlling for different types of derivatives. When we measure the overall effect of derivatives use on firm value, we find that FC derivatives use has no significant effect on firm 
value in the overall sample, in the statistically significant asymmetric sub-sample or in the sub-sample of non-asymmetric exposures.

The minor contributions of this study involve the exposure estimations themselves. By estimating exposures year by year, controlling for correlations between the USD and nonUSD currencies, and considering "good" and "bad" exposures this study offers a more detailed breakdown of magnitudes and directions of exchange rate exposures and how these exposures change in response to changes in the firm and its environment. ${ }^{8}$ It provides evidence that FC exposure is often asymmetric, spread evenly between "good" and "bad", and considerably more widespread than what is generally indicated in the literature, including the literature on asymmetric exposure. ${ }^{9}$ Over $65 \%$ of the firms in our sample have significant exposure of one kind or another over the period, and 52\% of the significant exposures are asymmetric.

\section{Sample selection and data}

To carry out the empirical analysis, the study uses a sample composed of the largest French non-financial firms for the years 2002-2005. French data for this period is well adapted to the research we propose. Measured as gross domestic product (GDP), France had the second largest economy in the euro zone and the $5^{\text {th }}$ largest in the world. ${ }^{10}$ According to the 2005 World Trade Organization International Trade Statistics, it was the world's fifth leading merchandise exporter and fourth leading importer. ${ }^{11}$ Foreign trade represented $51 \%$ of

\footnotetext{
${ }^{8}$ Since the USD represents more than $80 \%$ of French non-euro foreign trade transactions over the period under consideration, controlling for correlations between USD and non-USD exposure addresses the problem pointed out by Williamson (2001) that tests using a trade weighted basket of currencies may lack power if a firm is mostly exposed to only a few currencies within the basket. It also addresses Miller and Reuer's (1998) argument that a trade weighted index disregards the problem of low and negative correlations among exchange rates.

${ }^{9}$ Up to now, testing the relationship between FC exposure and FC derivatives use has been complicated by the fact noted above that the existing empirical results suggest that firms generally do not have significant exchange rate exposures.

${ }^{10}$ See United Nations Statistics Division http:/ /unstats.un.org.

${ }^{11}$ In commercial services, it was the fourth leading exporter and fifth leading importer.
} 
GDP, according to the 2004 CAF-FAB survey, and $25.6 \%$ of that (13\% of GDP) was outside the euro zone (see: Clark and Mefteh, 2011). It has a large number of firms with substantial foreign operations and FC derivatives use by French firms was widespread even after the introduction of the euro (e.g. Capstaff et al., 2007). ${ }^{12}$ The economy is highly industrialized and open with developed, generally unrestricted capital markets and trading partners that are predominantly in the same conditions. Thus, the financing and hedging decisions by the firms in our sample are likely to reflect economic and financial criteria rather than constraints imposed by shallow domestic capital markets, bureaucratic controls and the like. Finally and importantly, the USD represents more than $80 \%$ of French non-euro foreign trade transactions over the period under consideration. ${ }^{13}$ As we show in the following section, this concentration of FC risk on the USD makes it possible to eliminate or reduce some major estimation problems that have plagued other studies. ${ }^{14}$

The data is hand collected from risk management disclosures on FC derivatives use in annual reports starting from a sample of the 211 non-financial, French firms that comprise the SBF250 (the index for the largest 250 French firms) as of January 2002. FC users are defined as those firms that make any reference in their annual report to hedging their FC exposures and disclose the notional amount of FC hedged. The distribution of the FC derivatives activity disclosures of our sample over the period of study is collated in Table 1 . There is some movement between users and non-users as suggested by Aretz and Bartram (2011) with 70 users in 2002, 96 in 2003, 81 in 2004 and 88 in 2005.

The data for generating firm FC exposures and firm financial characteristics is obtained from DataStream. All data are as of the end of fiscal year, which, for our sample, coincides with the calendar year. Table 2 reports the industry distribution for the sample firms

\footnotetext{
${ }^{12}$ Nguyen et al. (2007) find that the use of FC derivatives was effective in managing exchange rate exposure both before and after the introduction of the euro with no apparent difference between the two periods.

13 "Le commerce extérieur de la France, site du ministère l'Économie, de l'industrie et de l'emploi, http://www.minefe.gouv.fr.

${ }^{14}$ This refers to the problems associated with a trade weighted index discussed in footnote 8 .
} 
based on the two-digit SIC classification. Sampled firms represent 11 different industries. Services and consumer durables have the highest representation comprising $21 \%$ and $21.5 \%$ of the sample respectively while petroleum (1.5\%), construction (3\%) and transportation (4.5\%) have the lowest. Sample descriptive statistics are presented in Table 3.

\section{Empirical analysis of FC exposures}

In this section we estimate the currency exposures of the firms in our sample. To estimate currency risk exposure defined by Dumas (1978), Adler and Dumas (1980), and Hodder (1982) as the effect of unanticipated exchange rate fluctuations on firm value, Jorion (1990) proposed a two-factor model with market returns as the dependent variable and percentage changes in the exchange rate as the explanatory variables.

$$
R_{i, t}=\beta_{i, 0}+\beta_{i, m} R_{m, t}+\beta_{i, x} R_{x, t}+\varepsilon_{i, t}
$$

where $R_{i t}$ is the firm's $i$ common stock return in period $t, R_{m, t}$ is the rate of return on the market index in period $t,{ }^{15}$ and $R_{x, t}$ is the movement in the trade weighted Euro exchange rate index for period $t{ }^{16}$ The coefficient $\beta_{i, m}$ measures firm i's return sensitivity to market fluctuations and $\beta_{i, x}$ describes the sensitivity of stock returns to unanticipated changes in exchange rates. Since the Euro index represents the price of one euro in units of foreign currencies, a statistically significant positive $\beta_{i, x}$ coefficient implies that an appreciation of the

\footnotetext{
${ }^{15}$ In equation (1), choice of the market risk factor will impact on the value and significance of the estimated exposure coefficients. For a country integrated into the international economic and financial system, the market risk factor should reflect international conditions as well as local conditions. It should also be independent of changes in the value of the currency so that estimates of currency risk exposure reflect total currency exposure and not only the residual exposure that is not covered by the market.

${ }^{16}$ The trade weighted Euro effective exchange covers 22 currencies: in order of weighting they are Great Britain, USA, Japan, Switzerland, Sweden, China, Hong Kong, Taiwan, Denmark, South Korea, Poland, Singapore, Czech Republic, Russia, Turkey, Hungary, Malaysia, India, Norway, Canada, Thailand and Brazil. This group of countries covers almost $97 \%$ of all foreign trade between the Euro area and the rest of the world. The weights adopted are those calculated by the OECD, after a double weighting that takes into account not only direct foreign trade between two counties but also of the presence other competing third party countries. (This definition is given by Datastream)
} 
domestic currency, the euro, has a positive impact on a firm's stock returns and a statistically significant negative $\beta_{i, x}$ implies a negative impact. $\varepsilon_{i, t}$ denotes the white noise error term.

Using a trade weighted basket of currencies to estimate sensitivity to exchange rate fluctuations has two major shortcomings. First, a trade weighted index disregards the problem of low and negative correlations across exchange rates (Miller and Reuer, 1998) and, second, tests may lack power if a firm is mostly exposed to only a few currencies within the basket (Williamson, (2001). We note that the USD represents more than $80 \%$ of French non-euro foreign trade transactions over the period under consideration. ${ }^{17}$ Based on these considerations, we introduce the bilateral EUR/USD exchange rate and orthogonalize the Euro-Index with respect to the USD by regressing the Euro-Index returns, noted $R_{x t}$, on the bilateral EUR/USD returns, noted $R_{u s, t}$. The obtained residuals from the regression, noted $R_{\text {res, }, \text {, }}$ represent the movements in the value of the euro due to currencies other than the USD.

In results, not reported here but available on request, we find that returns on the EUR/USD bilateral exchange rate are significant at the $1 \%$ level and account for $80 \%$ of returns on the total index $\left(\mathrm{R}^{2}=0.80\right)$. This result is interesting because the USD component of the Euro-index was only $22.9 \%$ over the period $2001-2003$ and $19.6 \%$ for $2004-2006$. This is evidence that the USD is a source of indirect FC exposure. It is not surprising because the dollar is a major anchor currency at the core of the international financial system. ${ }^{18}$ A change in the value of the dollar with respect to one currency has repercussions for all currencies tied to the dollar. Even when the dollar itself is not a direct target of currency traders, its role as the central currency in cross trades will cause its value to vary with repercussions for other currencies as well. By the same token, the prices of many raw materials, such as oil, gas, copper, iron, wheat and corn, to mention only a few, are tied to the USD. A change in the

\footnotetext{
17 "Le commerce extérieur de la France, site du ministère l'Économie, de l'industrie et de l'emploi, http://www.minefe.gouv.fr.

${ }^{18}$ For example, Clark et al. (2008) show that of the 90 de facto exchange rates they calculated over the period 1998-2002, 72\% were tied directly to the USD: $29 \%$ were fully pegged to the USD, $9 \%$ were partially pegged to the USD, and $34 \%$ were pegged to a basket that included the USD.
} 
value of the dollar with respect to the other major currencies will affect the prices of the commodities tied to the dollar as the well known consequences on individual economies brought about by currency devaluations/revaluations impact international supply and demand. ${ }^{19}$ The practical consequence is that the value of the USD can have unanticipated, indirect effects on currency exposures that render effective FC hedging extremely difficult.

A convenient methodology for investigating whether corporate FC exposure reacts differently to positive (appreciations) and negative (depreciations) moves in the exchange rate involves separating the vector of exchange rate returns into two vectors, one with positive moves and zeroes everywhere else and the other with negative moves and zeroes everywhere else. ${ }^{20}$ Applying this methodology, we re-write equation (1) by decomposing $R_{u s, t}$ and $R_{\text {res }, t}$ into its positive and negative components as follows:

$$
R_{i, t}=\beta_{0}+\beta_{i, m} R_{m, t}+\beta_{i, u s}^{A p p} R_{u s, t}^{A p p}+\beta_{i, u s}^{D e p} R_{u s, t}^{D e p}+\beta_{i, r e s}^{A p p} R_{r e s, t}^{A p p}+\beta_{i, r e s}^{D e p} R_{r e s, t}^{D e p}+\varepsilon_{i, t}
$$

where the superscript "App" refers to appreciations of the euro and the superscript "Dep" refers to depreciations. $R_{u s, t}^{A p p}\left(R_{u s, t}^{D e p}\right)$ takes the value of positive (negative) moves in the EUR/USD exchange rate and zeroes everywhere else, and $R_{r e s, t}^{A p p}\left(R_{r e s, t}^{D e p}\right)$ takes the value of positive (negative) moves in the EUR/RES exchange rate and zeroes everywhere else. Thus, $\beta_{i, u s}^{\text {App }}\left(\beta_{i, u s}^{\text {Dep }}\right)$ measures exposure to appreciations (depreciations) of the euro with respect to the USD and $\beta_{i, r e s}^{A p p}\left(\beta_{i, r e s}^{\text {Dep }}\right)$ measures exposure to appreciations (depreciations) of the euro with respect to non-USD currencies. To account for France's integration in international capital

\footnotetext{
19 See, for example, the elasticities and absorption approach to exchange rate fluctuations, the balance of payments and economic adjustment referred to in the introduction and footnote 1.

${ }^{20}$ See for example, Clark and Mefteh (2011).
} 
markets and avoid a potential omitted variable problem with the local index, ${ }^{21}$ we use the MSCI World Index as the market risk factor. ${ }^{22,23}$

To capture the variations in exposures due to changing economic conditions and the evolution of individual firms, the regression is estimated for each fiscal year and for each firm using weekly returns. Table 4 reports the results of the FC exposures estimated from equation (2) for the four years: 2002-2005. There are 94 significant exposure coefficients (5\% level) in 2002, 114 in 2003, 129 in 2004 and 130 in $2005 .^{24}$ Overall, there are 467 significant exposures and 139 firms, 65\% of the sample, had at least one significant exposure over the investigation period. ${ }^{25}$ Thus, after controlling for asymmetry and correlations between the USD and other currencies, it seems that significant exposures are considerably more widespread than what is generally indicated in the literature. ${ }^{26}$

While the model presented in equation (2) makes it possible to directly estimate coefficients associated with currency appreciations and depreciations, it does not offer a direct test of asymmetry. The Koutmos and Martin (2003) (KM) model offers a direct test for asymmetry, although it does not directly compute the coefficients for euro depreciations. ${ }^{27}$ The asymmetry tests using the KM model are collated in Table 5. They show that a

\footnotetext{
${ }^{21}$ It also avoids the size problem studied by Bodnar and Wong (2003).

${ }^{22}$ The MSCI World Index is a free float-adjusted market capitalization index that is designed to measure global developed market equity performance. As of June 2006 the MSCI World Index consisted of the following 23 developed market country indices: Australia, Austria, Belgium, Canada, Denmark, Finland, France, Germany, Greece, Hong Kong, Ireland, Italy, Japan, Netherlands, New Zealand, Norway, Portugal, Singapore, Spain, Sweden, Switzerland, the United Kingdom and the United States (This definition is given by Morgan Stanley Capital International).

23 As a robustness check, we also estimated the exposure coefficients using the Jorion approach in equation 1, using the returns on the local SBF250 represent the market factor. The results from this estimation, available on request, are similar but weaker with a lower rate of significant coefficients.

${ }^{24}$ Most studies consider only one type of exposure and report their results as percentages. When several types of exposure are considered, the number of significant exposures and the number of firms affected gives a better overall view of exposure than percentages of specific exposures. Exposures broken down by percent are available on request.

${ }^{25}$ In results not reported but available on request, when asymmetry is not considered, there are only 176 significant exposures. .

${ }^{26}$ The seminal empirical research of Jorion (1990) shows that only $5.2 \%$ of his sample exhibits significant exchange rate exposure. Choi and Prasad (1995) document that only $15 \%$ of their sample experiences significant exchange risk sensitivity. $\mathrm{He}$ and $\mathrm{Ng}$ (1998) report that about $25 \%$ of their sample has significant exchange rate exposure. For French firms, Nguyen et al. (2007) find 32\% significant exposure rates in the pre-euro year of 1996 and $11 \%$ in the post euro year of 2000.

${ }^{27}$ See Appendix for more information on KM's model.
} 
substantial amount of FC exposure exhibited in our sample is asymmetric. Overall, there are 242 statistically significant (5\% level) asymmetric coefficients, almost $52 \%$ of the total number of significant exposure coefficients estimated in equation (2), and they are spread more or less evenly over the four years. Asymmetry is more pronounced for non-USD exposures, 135 for non-USD exposures against 107 for USD exposures. In every year except 2003 non-USD asymmetries were much higher than those for USD asymmetries. The widespread existence of asymmetric FC exposure is evidence that opportunities for value adding hedging strategies do exist. The higher number of asymmetric non-USD exposures suggests that there are more opportunities with respect to non-USD currencies.

\section{Empirical analysis of the effect of corporate derivatives use on FC exposure and firm value}

This section is in two parts. The first part investigates the relationship between the use of FC derivatives and shareholder value through their effect on FC exposure. The assumption is that higher average returns create shareholder value. Thus, we test two hypotheses:

1) The derivatives based strategies create shareholder value through an increase in average returns by reducing the absolute value of "bad" exposures more than the absolute value of "good" exposures.

2) The derivatives based strategies create shareholder value through an increase in average returns by recognizing exposure asymmetries and effectively exploiting them by reducing the absolute value of "bad" exposures more than the absolute value of "good" exposures.

The second part of this section investigates whether or not FC derivatives use has a significant effect on shareholder value through its effect on Tobin's Q. The third hypothesis we test is:

3) Derivatives use increases firm value measured as Tobin's $Q$. 
We test this relationship on the whole sample and on subsamples of firms with asymmetric exposure to the USD, firms with asymmetric exposure to non-USD, and firms with asymmetric exposures only.

In both parts, the empirical study is set at panel level for the sub sample of firms disclosing that use FC derivatives as described in table 1.

\section{FC derivatives use and FC exposure}

To study the effectiveness of FC derivatives use on FC exposure we build on a long list of earlier studies (e.g. He and Ng, 1998; Nydahl, 1999; Wong, 2000, Allayannis and Ofek, 2001, Nguyen and Faff, 2003 and Hagelin and Prambourg, 2004) that examine the determinants of currency exposure in a cross sectional regression with the absolute value of the exposure coefficient as the dependent variable. To control for asymmetric exposures, we segment the sample into four exposure groups: exposure to appreciations of the EUR/USD, exposure to depreciations of the EUR/USD, exposure to appreciations of the EUR/RES and exposure to depreciations of the EUR/RES. To test whether FC derivatives use affects good and bad exposures differently, we break DERIV into two separate vectors, one vector associated with positive exposures and zeroes everywhere else and the other associated with negative exposures and zeroes everywhere else. The other explanatory variables follow Jorion (1990), Bodnar et al. (1996), Allayannis and Ofek (2001) and Nguyen and Faff (2003) and include the percentage of sales in foreign currency (FSTS) and firm size (SIZE). ${ }^{28}$ This gives the following system of equations:

$$
\begin{gathered}
\left|\beta_{i t, u s}^{A p p}\right|=\alpha_{1}+\alpha_{2} D_{E R I V} \times u s d_{+}^{A p p}+\alpha_{3} D E R I V_{i, t} \times u s d_{-}^{A p p}+\alpha_{4} \text { FSTS }_{i, t}+\alpha_{5} \operatorname{SIZE}_{i, t}+\eta_{a, i, t} \\
\left|\beta_{i t, u s}^{\text {Dep }}\right|=\alpha_{6}+\alpha_{7} \text { DERIV }_{i, t} \times u s d_{+}^{\text {Dep }}+\alpha_{8} D E R I V_{i, t} \times u s d_{-}^{\text {Dep }}+\alpha_{9} \text { FSTS }_{i, t}+\alpha_{10} \operatorname{SIZE}_{i, t}+\eta_{b, i, t}
\end{gathered}
$$

\footnotetext{
${ }^{28}$ For the definition and descriptive statistics of the variables in this section, see table 2.
} 


$$
\begin{aligned}
& \left|\beta_{i t, r e s}^{\text {App }}\right|=\alpha_{11}+\alpha_{12} \text { DERIV }_{i, t} \times \operatorname{resd}_{+}^{\text {App }}+\alpha_{13} \text { DERIV }_{i, t} \times \operatorname{resd}_{-}^{\text {App }}+\alpha_{14} \text { FSTS }_{i, t}+\alpha_{15} \operatorname{SIZE}_{i, t}+\eta_{c, i, t} \\
& \left|\beta_{i t, \text { res }}^{\text {Dep }}\right|=\alpha_{16}+\alpha_{17} \text { DERIV }_{i, t} \times \operatorname{res}_{+}^{\text {Dep }}+\alpha_{18} \text { DERIV }_{i, t} \times \operatorname{resd}_{-}^{\text {Dep }}+\alpha_{19} \operatorname{FSTS}_{i, t}+\alpha_{20} \operatorname{SIZE}_{i, t}+\eta_{d, i, t}
\end{aligned}
$$

where $\beta_{i, u s}^{A p p(D e p)}$ is the exposure to appreciations (depreciations) of the EUR/USD exchange rate; $\beta_{i, r e s}^{A p p(D e p)}$ is the exposure to appreciations (depreciations) of the EUR/RES exchange rate. Note again that the exchange rate is expressed as the number of units of foreign currency for one euro. DERIV is the notional amount of FC derivatives divided by total assets. The control variables include foreign sales, FSTS, and firm size, SIZE. The variables $u s d_{+}^{A p p}$, $u s d_{-}^{A p p}$, $u s d_{+}^{D e p}, u s d_{-}^{D e p}, r e s d_{+}^{A p p}, r e s d_{-}^{A p p}, r e s d_{+}^{D e p}, r e s d_{-}^{D e p}$ are dummy variables. $u s d_{+}^{A p p}\left(u s d_{-}^{A p p}\right)$ takes the value 1 if $\beta_{i, u s}^{A p p}$ is positive (negative) and the Euro appreciates with respect to US Dollar. $u s d_{+}^{D e p}\left(u s d_{-}^{D e p}\right)$ takes the value 1 if $\beta_{i, u s}^{D e p}$ is positive (negative) and the Euro depreciates with respect to US Dollar. $r e s d_{+}^{A p p}\left(r e s d_{-}^{A p p}\right)$ takes the value 1 if $\beta_{i, r e s}^{A p p}$ is positive (negative) and the Euro appreciates with respect to other currencies. $r e s d_{+}^{D e p}\left(r e s d_{-}^{\text {Dep }}\right)$ takes the value 1 if $\beta_{i, \text { res }}^{\text {Dep }}$ is positive (negative) and the Euro depreciates with respect to other currencies. The error terms are represented by the $\eta_{i, t}$.

Thus, when the dependent variable refers to appreciations of the euro with respect to the USD $\left(\beta_{i, u s}^{A p p}\right), \alpha_{2}$ measures the effect of derivatives use on good exposures (positive exposure to appreciations of the euro) and $\alpha_{3}$ measures the effect of derivatives use on bad exposures (negative exposure to appreciations of the euro). When the dependent variable refers to depreciations of the euro with respect to the USD $\left(\beta_{i, u s}^{D e p}\right), \alpha_{7}$ measures the effect of derivatives use on bad exposures (positive exposure to depreciations of the euro) and $\alpha_{8}$ measures the effect of derivatives use on good exposures (negative exposure to depreciations 
of the euro). Using the same reasoning with respect to RES, $\alpha_{12}\left(\alpha_{13}\right)$ measures the effect of good (bad) exposures to appreciations of the euro and $\alpha_{17}\left(\alpha_{18}\right)$ measures the effect of bad (good) exposures to depreciations of the euro. This makes it possible to test whether shareholder value is being created through the use of derivatives by market returns. For example, consider the case where the dependent variable is exposure to appreciations of EUR/USD (EUR/RES). If $\alpha_{2}$ and $\alpha_{3}\left(\alpha_{12}\right.$ and $\left.\alpha_{13}\right)$ are not significant, this is evidence of no effect of derivatives use on exposure and, thus, no effect on market returns and shareholder value. If they are significant and positive, it suggests that derivatives use is increasing exposure and might be a signal of speculative activity. If they are significant and negative, it suggests that derivatives use is decreasing exposure. For derivatives use to signal a significant, positive net effect on market returns and shareholder value, $\alpha_{2}\left(\alpha_{12}\right)$ should be greater than $\alpha_{3}\left(\alpha_{13}\right)$, it should be statistically significant, and the two coefficients should be statistically different. The same type of reasoning holds for exposures to depreciations of the euro, where $\alpha_{8}$ and $\alpha_{18}$ are estimates of good exposures and $\alpha_{7}$ and $\alpha_{17}$ are estimates of bad exposures.

One salient problem with the estimation of the system of equations (equations $3 a, 3 b$, 3c and 3d) is that DERIV may be endogenous (see Aretz and Bartram (2011) for a discussion of endogeneity). To address this, we estimate the system of equations using three-stage least squares (3SLS), where the disturbance terms are assumed to be contemporaneously correlated. $^{29}$

\footnotetext{
${ }^{29}$ We instrument DERIV, the notional amount of FCD, with the following instruments: total capital expenditure (CAPEX), foreign sales (FSTS), dividend (DY), and leverage (LEV). The $R^{2}$ and $F$ statistics, of the unreported instrument equation, are 0.28 and 10.56 respectively, confirming the quality of these instruments. Table 6 shows that the Hausman test provides significant evidence of an endogeneity bias at the $5 \%$ level between the absolute value of FC exposure and FC derivatives use, suggesting instrumentation of FC derivatives use. The AndersonCanon test is significant and indicates that our instruments are identified (i.e., are correlated with endogenous variables). The Cragg-Donald $F$-statistic is greater than the critical value provided by Stock and Yogo (2005), indicating that the null hypothesis of weak instruments can be rejected.
} 
The results are reported in panel A of Table 6. Columns 2 to 5 include all firms in the sample, where data on FC derivatives use and control variables is available. All of the interacted DERIV terms are negative and six of the eight are significant at the 5\% level, which is evidence that the use of derivatives is reducing exposures, both good and bad. Since overall exposure is being reduced, this is evidence that derivatives are being used for hedging. The Wald-test at the bottom of the table, however, shows that there is no statistical difference between any of the four pairs of coefficients. This is evidence that use of derivatives is not increasing market returns and shareholder value.

One explanation for the failure to exploit "good" exposures could be associated with cost and the difficulty of accurately assessing exchange rate volatility and the actual exposures facing the firm. Forwards, futures or swaps, which are cheap but symmetric in that they limit both good and bad exposures, might be favoured over option style derivatives that are expensive but allow for asymmetric outcomes. The bias towards cheaper forwards, futures and swaps, even when an option based derivative would be more appropriate, could be accentuated if there is a low level of accuracy of exchange rate volatility and exposure estimates. Accurate exposure estimation is difficult for at least two reasons. First of all, the direct effects of exchange rate fluctuations on the value of outstanding foreign currency cash flows can be obscured by cross correlations and secondary effects that are easily observable. For example, the USD counted for only about $21 \%$ of the composition of the trade weighted effective Euro index over the period 2002-2005. However, when we estimated the total effect of the USD on the index, we found that it counted for $80 \%$ of movements in the index, almost four times the direct effect associated with the weight for constructing the index. This is evidence of the existence of indirect effects, which are likely to be difficult to ascertain with a high degree of accuracy, playing a substantial role in determining FC exposure. Secondly, besides the direct effects on the value of outstanding foreign currency cash flows, complex 
relationships between exchange rates and other economic factors, such as relative prices, income, expenditure, interest rates, and supply and demand, to mention only a few, that are difficult to estimate with any accuracy can have a significant impact on individual firm value and make it difficult to design and implement an effective FC hedging strategy. ${ }^{30}$

To explore the angle that uncertainty about exposures is driving the results in columns 2 to 5 , we re-do the tests on the sub-sample of asymmetric exposures. The hypothesis here is that since these exposures are different and statistically significant, it should be easier for firms to identify and exploit the resulting opportunities. The results are reported in columns 6 to 9. Columns 6 and 7 (columns 8 and 9) include only those firms that have significant asymmetric exposures to the USD (RES). The coefficients on DERIV in column 6 associated with appreciations of the euro with respect to the USD have the right sign but neither are significant and, from the Wald-test at the bottom of the table, they are not statistically different from each other. In column 7 the coefficient on the bad exposure $a_{7}$ has the wrong sign but is not statistically significant. The coefficient for the good exposure $a_{8}$, however, is positive and significant. This could be weak evidence of effective use of FC derivatives, but the Wald-test at the bottom of the table indicates that there is no statistical difference between the two coefficients. The coefficients $a_{12}$ and $a_{13}$ in column 8 are not significant and have the wrong signs. The coefficients $a_{17}$ and $a_{18}$ in column 9 are not significant and $a_{18}$, which has the wrong sign, has a larger absolute value than $a_{17}$. There is no statistically significant difference between either of these two pairs of coefficients. The foregoing results are evidence that asymmetric exposures are not being exploited any more effectively with FC derivatives than non-asymmetric exposures. In fact, it looks like derivatives are not even effective in reducing exposures when they are asymmetric.

\footnotetext{
${ }^{30}$ See, for example, the elasticities and absorption approach to balance of payments in Meade (1951), Alexander (1952 and 1959), Pearce (1961), Tsiang (1961), Gerakis (1964) and Caves and Johnson (1968).
} 
To test the effect of the individual derivative products on exposures, we created four dummy variables from the sub-sample of firms that provided data on their hedging instruments and re-ran the system of equations (3a, 3b, 3c and 3d). FORWARD takes the value of 1 if the firm uses forward contracts and 0 otherwise, SWAP takes the value of 1 if the firm uses swaps and 0 otherwise, OPTION takes the value of 1 if the firm uses vanilla options and 0 otherwise and OTHERS takes the value of 1 if the firm uses another type of derivative, such as exotic options, and 0 otherwise. The results are reported in table 7 . Columns 2 to 5 refer to the whole sub-sample of firms reporting the relevant information and columns 6 to 9 refer to the sub-sample of firms with statistically significant asymmetric exposures reporting relevant information. The option based hedging instruments, OPTION and OTHERS, are never significant in either the whole sub-sample or the asymmetric sub-sample. FORWARD and SWAP are negative and significant but only for the whole sub-sample. Interestingly, all but two of the interacted DERIV coefficients become insignificant. ${ }^{31}$ Taken together with Table 6, these results are evidence that symmetric payoff derivatives (forwards, futures and swaps) are driving the exposure reduction in general, but none of the instruments seem to be effective for asymmetric exposures.

The evidence from the foregoing tests does not support the hypothesis that derivatives based strategies create shareholder value through an increase in average returns by reducing the absolute value of "bad" exposures more than the absolute value of "good" exposures. Nor does it support the hypothesis that derivatives based strategies create shareholder value through an increase in average returns by recognizing exposure asymmetries and by effectively exploiting them by reducing the absolute value of "bad" exposures more than the absolute value of "good" exposures.

\footnotetext{
${ }^{31}$ In a further robustness test not reported here, we do the same tests without interacted DERIV with similar results.
} 


\section{FC derivatives and firm value}

Failure to exploit "good" exposures even when "good" and "bad" exposures are asymmetric does not mean that derivatives use is not creating value. As discussed in the introduction, according to the positive theory of hedging, exposure reduction itself can create value by simultaneously reducing external claims on the cash flow stream flowing from the firm's assets. Such claims include taxes paid to government by the firm; bankruptcy costs (both direct and indirect) paid to accountants, lawyers and the firm's non-investor stakeholders; and/or agency costs to align managerial interests with the interests of capital suppliers. Each has the potential to provide an explanation for the corporate demand for hedging. In order for hedging with FC derivatives to be effective, the overall gains must be greater than the costs. In this section we test whether the use of FC derivatives fulfills this condition and adds value to the firm.

To allow direct comparison with earlier studies we use Tobin's $Q$ as a measure of firm value (e.g., Allayannis and Weston, 2001; Pramborg; 2005). ${ }^{32}$ In the same vein, to be consistent with prior studies on the determinants of firm value, along with FC derivatives use, we include the following firm specifics: ${ }^{33}$ firm size $\left(\mathrm{SIZE}^{34}\right)$, the natural logarithm of the firm's total assets ; profitability (PROF), the ratio of earnings before interest and taxes to total assets; leverage (LEV), the ratio of book value of long term debts to total assets; investment opportunities (CAPEX), the ratio of total capital expenditure to total assets; the ability to access financial markets (DY), the dividend per share divided by the share price; liquidity

\footnotetext{
${ }^{32}$ Tobin's $Q$ is the ratio of market value of assets to the book value of assets, where the market value of assets is measured as the book value of assets less the book value of equity plus the market value of equity. See table 3 for descriptive statistics.

${ }^{33}$ For the definition and descriptive statistics of the variables in this section, see table 3.

${ }^{34}$ As a robustness check, we also use the log of total sales to proxy SIZE. The results, available on request, are substantially the same.
} 
(QUICK), the ratio of cash plus marketable securities to short term liabilities. Hereafter, we discuss the possible impact of the control variables on firm value

Nance et al. (1993), Mian (1996) and Géczy et al. (1997), have found that large firms are more likely to use derivatives due to the high start-up costs necessary to develop a hedging program. Others, such as Peltzman (1977), and Allayannis and Weston (2001) find contrary results. Thus, we have no prior on the sign of the relationship between firm size and Tobin's Q. With respect to profitability, it is generally held that the marketplace is likely to reward more profitable firms with higher values. Thus, we expect profitability to be positively related to Tobin's Q.

Since a firm's capital structure may be positively related to its value through the tax shield on the one hand and negatively related through a higher probability of financial distress on the other (see, for example, Graham and Rogers, 2002), we have no expectation on the sign of the relationship between leverage and Tobin's Q.

Froot et al. (1993) and Géczy et al. (1997) argue that firms that hedge are more likely to have more investment opportunities. Allayannis and Weston (2001) find weak evidence of a positive relation between investment opportunities and firm value. Therefore, we expect a positive relationship between investment opportunities and Tobin's Q.

With respect to firms' access to financial markets, Jin and Jorion (2006), who used dividends to proxy for financial constraints, argue that "if hedgers have limited access to financial markets, their Tobin's Q ratios may be high because they are constrained to take on only those projects with the highest NPVs". Given this interpretation, they expect a negative relationship. Allayannis and Weston (2001), who also used dividends to proxy for financial constraints, argue that if hedgers forego projects because they are not able to obtain the necessary financing, their Tobin's Q may remain high because they undertake only positive NPV projects (see also Lang and Stulz 1994, and Servaes 1996). On the other hand, dividends 
can be viewed as a positive signal from management, which should imply a positive coefficient". For example, Fazzari et al. (1988) argue that the greater the dividend yield is, the lower is the probability that the firm is financially constrained. Thus, we have no prior expectation on the sign of the relationship between dividends and Tobin's Q.

Firms that are cash constrained may have higher Tobin's Qs because they are more likely to invest in predominantly positive NPV projects. This follows from the free cash flow argument of Jensen (1986) that firms with excess free cash flow are more likely to invest in projects with negative NPV. Thus, we expect a negative relationship between QUICK and Tobin's Q.

The results on the determinants of firm value are presented in panel A of table 8 . Column 2 refers to the whole sample, column 3 to the sub-sample of asymmetric exposures, columns 4 and 5 to the asymmetric sub-sample broken down by currency, and column 6 to the sub-sample of all non-asymmetric exposures. Where the control variables are concerned, PROF and QUICK are positive and significant for the whole sample while firm size is negative and significant. For the asymmetric sub-sample, DY is positive and significant while SIZE and LEV are negative and significant.

Turning to FC derivatives use, DERIV, is not significant for the sample as a whole nor for the asymmetric sub-sample taken as a whole or broken down by asymmetric exposure type (see columns 4 and 5) nor for the sub-sample of all non-asymmetric exposures (column 6). In fact, it is negative for the whole asymmetric sub-sample (columns 3,4 and 5). All this is evidence that the use of FC derivatives does not create value for the firm. Combined with the results in Table 6, it looks like FC derivatives use is effective in reducing risk but that the gain from risk reduction is not large enough to offset the costs.

In panel $\mathrm{B}$ of table 8 we consider the effect of individual hedging strategies by including 3 dummy variables. The first refers to firms that use only derivatives with 
symmetric payoffs, noted SYMMETRIC, that takes the value of 1 if the firm uses only forwards and/or swaps and 0 otherwise. The second refers to firms that use only option type derivatives with asymmetric payoffs, noted ASYMMETRIC, that takes the value of 1 if the firm uses only options and/or others and 0 otherwise. The third refers to firms that use both types of derivatives, noted BOTH, that takes the value of 1 if the firm uses both forwards and/or swaps and options and/or others and 0 otherwise. As in panel A, column 7 refers to the whole sample, column 8 to the sub-sample of asymmetric exposures, columns 9 and 10 to the asymmetric sub-sample broken down by currency and column 11 to the sub-sample of all non-asymmetric exposures. None of the derivatives linked variables, including DERIV, is significant at any conventional level in any of the models. ${ }^{35}$ Thus, we find no evidence that FC derivatives, when taken as a whole or when broken down by symmetric/non-asymmetric payoff profiles, contribute anything to firm value.

\section{Conclusion}

This paper looks at corporate FC exposure and analyzes the effectiveness of derivative based corporate hedging strategies in creating shareholder value. It proceeds in three stages. After controlling for nonlinearity and correlations between USD and non-USD currencies, stage 1 provides nuanced estimates of $\mathrm{FC}$ exposures and evidence that $\mathrm{FC}$ exposure is more widespread than what has been found in the literature up to now. Sixty-five percent of our sample is significantly affected by currency movements and more than half of this exposure is asymmetric with respect to appreciations and depreciations of the euro.

\footnotetext{
${ }^{35}$ In a further robustness test not reported here, we do the same tests without DERIV with similar results.
} 
Stage 2 groups the coefficients in stage 1 by currency (USD and non-USD) into "good" exposures and "bad" exposures. When we distinguish between the different combinations of appreciations, depreciations, positives and negatives, our results show that FC derivatives use does reduce overall exposure, which is evidence that derivatives are being used for hedging. However, there is no statistical difference between any of the four pairs of "good" and "bad" coefficients and symmetric payoff derivatives are found to be driving the risk reduction. Furthermore, for the asymmetric sub-sample there is no significant statistical relationship between derivatives use and exposures. This is evidence that the hedging strategies are not exploiting the "good" exposures to create shareholder value even when the "good" and "bad" exposures are statistically asymmetric. A possible explanation for this failure is that due to the complex interrelationships across the range of economic and financial variables, actual exposures may be difficult or even impossible to estimate accurately. The huge difference between the official weight of the USD in the Euro index and its actual effect on index movements are preliminary evidence that this might, in fact, be the case.

Stage 3 uses the groupings of stage 2 to test whether there is a positive net effect of FC derivatives use on firm value. This stage recognizes that, although there is no increase in shareholder value associated with derivatives generated increases in market returns, it is still possible that the use of FC derivatives are creating value by reducing external claims on firm cash flows. When we measure the overall effect of derivatives use on firm value, the effect is positive but not significant. On the asymmetric sub-sample the effect is negative and not significant. There is also no significant relationship between any of the three hedging strategies (symmetric, asymmetric and both) and firm value. This leads to the conclusion that the use of FC derivatives is not a value adding activity for the French firms in our sample.

There are several reasons why active FC derivatives use may ultimately have little or no beneficial effect on firm performance. First of all, as argued by Copeland and Joshi (1996) 
and reported by Hagelin and Pramborg (2004), there is the possibility that the risk management program is ineffective in reducing exposure to losses, which is what our results suggest. Indeed, price fluctuations in the variable to be hedged may involve changes in other economic factors, which can make hedging programs inappropriate and in some cases increase exposure. Even when hedging programs are appropriate and well executed, gains from hedging may be inadequate to cover the substantial costs in financial, physical and human resources required to conceive and implement the hedging strategy. Secondly, as Tufano (1998) has shown, hedging provides a shield for monitoring from external capital providers and, if management also considers value-reducing investment opportunities (negative net present value), permits management to fund these projects with its protected capital. Finally, cloaked in the hedging argument for cover, derivatives may be used for speculative purposes rather than risk reduction, which would have the effect of increasing exposure. ${ }^{36}$ Speculation, however, does not seem to be a factor in our sample, except perhaps, for the non-asymmetric sub-sample.

Although our results will have to be confirmed and extended in further research, preliminary policy implications for French firms are that there is potential for using FC derivatives to exploit the observed exposures. This implies consecrating resources to identifying the actual FC exposures faced by the firm. The outcome, of course depends on whether the incremental gains outweigh the incremental costs.

\footnotetext{
${ }^{36}$ Géczy et al. (1997) find that US firms that readily admit to speculating in an anonymous survey do not report these activities in their financial reports. In the majority of cases annual report disclosures contradict the survey responses.
} 


\section{References}

Adler, M., \& Dumas, B. (1984). Exposure to currency risk: definition and measurement. Financial Management, 13, 41-50.

Alexander, S.S. (1952). Effects of devaluation on a trade balance. IMF Staff Papers, 263278.

Alexander, S.S. (1959). Effects of a devaluation: a simplified synthesis of elasticities and absorption approaches. American Economic Review, 49, 22-42.

Allayannis, G., \& Ihrig, J. (2001). Exposure and markups. Review of Financial Studies, 14, 805-835.

Allayannis, G., \& Ofek, E. (2001). Exchange rate exposure, hedging and the use of foreign currency derivatives. Journal of International Money and Finance, 20, 273-296.

Allayannis, G., \& Weston, J. (2001). The use of foreign currency derivatives and firm market value. Review of Financial Studies, 14, 243-276.

Allayannis, G., Lel, U., \& Miller, D. (2009). Corporate governance and the hedging premium around the world. Working paper, Darden School University of Virginia, Charlottesville, VA.

Amihud, Y. (1994). Exchange rates and the valuation of equity shares. In: Amihud, Y., Levich, R.M. (Eds.), Exchange rates and corporate performance. Irwin, New York, 4959.

Aretz, K., \& Bartram, S. (2011). Corporate hedging and shareholder value. Journal of Financial Research, 33, 317-371.

Bartram, S. (2004). Linear and nonlinear foreign exchange rate exposures of German non financial corporations. Journal of International Money and Finance, 23, 673-699.

Bartram, S.M., Brown, G.W., \& Minton, B. (2010). Resolving the exposure puzzle: the many facets of foreign exchange exposure. Journal of Financial Economics 95, 148-173.

Belghitar, Y, Clark, E., \& Judge, A. (2008). The value effects of foreign currency and interest rate hedging: the UK evidence. International Journal of Business, 13, 43-60.

Berkman, H., \& Bradbury, M. (1996) Empirical evidence on the corporate use of derivatives. Financial Management, 25, 5-13.

Bodnar, G.M., \& Gentry, W.M. (1993). Exchange-rate exposure and industry characteristics: Evidence from Canada, Japan and the US. Journal of International Money and Finance, 12, 29-45.

Bodnar, G.M., Hayt, G.S., Marston, R.C., \& Smithson, C.W. (1996). Wharton survey of derivatives usage by US non-financial firms. Financial Management, 25, 113-133.

Bodnar, G.M., Dumas, B. \& Marston, R.C. (2002). Pass-through and exposure. Journal of Finance, 57, 199-231.

Bodnar, G.M., \& Wong, M.H.F. (2003). Estimating exchange rate exposures: issues in model structure. Financial Management, 32, 35-67.

Booth, L., \& Rotenberg, W. (1990). Assessing foreign exchange exposure: theory and application using Canadian firms. Journal of International Financial Management and Accounting, 2, 1-22.

Campbell, J. (1996). Understanding risk and return. Journal of Political Economy, 104, 298345.

Capstaff, J., Marshall, A., \& Hutton, J. (2007). The introduction of the Euro and derivatives use in French firms. Journal of International Financial Management and Accounting, 18, $1-17$.

Caves, R. E., \& Johnson, H.G. (1968). Readings in international economics, Homewood, Illinois: Irwin. 
Choi, J.J., \& Prasad, A.M. (1995). Exchange risk sensitivity and its determinants: a firm and industry analysis of US multinationals. Financial Management, 24, 77-88.

Clark, E.A., \& Mefteh, S. (2011). Asymmetric foreign currency exposures and derivatives use: evidence from France. Journal of International Financial Management and Accounting, 22, 28-47.

Clark, E.A., \& Judge, A. (2009). Foreign currency derivatives versus foreign currency debt and the hedging premium. European Financial Management 1,5, 606-642.

Clark, E.A., Zenaidi, A. \& Baccar, S. (2008). Capital market integration, currency crises and exchange rate regimes. International Journal of Finance and Economics, 13, 280-306.

Copeland, T., \& Joshi, Y. (1996). Why derivatives don't reduce FX risk. The Kinsey Quarterly, 1, 66-78.

Di Iorio, A., \& Faff, R. (2000). An analysis of asymmetry in foreign currency exposure of the Australian equities Market. Journal of Multinational Financial Management, 10, 133-159.

Dumas, B. (1978). The theory of the trading firm revisited. Journal of Finance, 33, 10191029.

Fazzari, S., Hubbard, R., \& Petersen, B. (1988). Finance constraints and corporate investment. Brookings Papers on Economic Activity, 1, 141-195.

Flood, E.Jr. \& Lessard, D.R. (1986). On the measurement of operating exposure to exchange rates: a conceptual approach. Financial Management, 15, 25-37.

Froot, K.A., Scharfstein, D.S., \& Stein, J.S. (1993). Risk management: coordinating corporate investment and financing Policies. Journal of Finance, 48, 1629-1658.

Géczy, C., Minton, B.A., \& Schrand, C. (1997). Why firms use currency derivatives. Journal of Finance, 52, 1323-1354.

Gerakis, A. S. (1964). Recession in the initial phase of a stabilization program: the experience of Finland. IMF Staff Papers, 11, 434-445.

Goldberg, S.R., Godwin, J.H., Kim, M.S., \& Tritschler, C.A. (1998). On the determinants of corporate usage of financial derivatives. Journal of International Financial Management and Accounting, 9, 132-166.

Graham, J., \& Rogers, D. (2002). Do firms hedge in response to tax incentives? Journal of Finance, 57, 815-839.

Griffin, J.M., \& Stulz, R.M. (2001). International competition and exchange rate shocks: a cross-country industry analysis of stock returns. Review of Financial Studies, 14, 215241.

Guay, W.R., \& Kothari, S.P. (2003). How much do firms hedge with derivatives? Journal of Financial Economics, 70, 423-461.

Hagelin, N., 2003, Why firms hedge with currency derivatives: An examination of transaction and translation exposure. Applied Financial Economics 13, 55-69.

Hagelin, N., \& Prambourg, B. (2004). Hedging foreign exchange exposure: risk reduction from transaction and translation exposure. Journal of International Financial Management and Accounting, 15, 1-20.

Hagelin, N., Holmen, M., Knopf, J.D., \& Pramborg, B. (2007). Managerial stock options and the hedging premium. European Financial Management, 13, 721-741.

He, J., \& Ng, L.K. (1998). The Foreign exchange exposure of Japanese multinational corporations. Journal of Finance, 2, 733-752.

Heaney, R.A., \& Winata, H. (2005), Use of derivatives by Australian companies. PacificBasin Finance Journal, 13, 411-430.

Hodder, J.E. (1982). Exposure to exchange rate movements. Journal of International Economics, 13, 375-386. 
Howton, S.D., \& Perfect, S.B. (1998). Currency and interest derivatives use in US firms. Financial Management, 27, 111-121.

Jensen M.C. (1986). Agency costs of free cash flow, corporate finance, and takeovers, American Economic Review, 76, 323-329.

Jin, Y., \& Jorion, P. (2006). Firm value and hedging: evidence from US oil and gas produces. Journal of Finance, 56, 510-536.

Jorion, P. (1990). The exchange rate exposure of US multinationals. Journal of Business, 63, 331-345.

Kedia, S., \& Mozumdar, A. (2003). Foreign currency denominated debt: An empirical examination. Journal of Business, 76, 521-46.

Kim, Y.S., Mathur, I., \& Nam, J. (2006). Is operational hedging a substitute for or a complement to financial hedging? Journal of Corporate Finance, 12, 834-853

Koutmos, G., \& Martin, A.D. (2003). Asymmetric exchange rate exposure: theory and evidence. Journal of International Money and Finance, 22, 365-383.

Krishnamoorthy, A. (2001). Industrial structure and the exchange rate exposure of industry portfolio returns. Global Finance Journal, 12, 285-297.

Lang, L., \& Stulz, R. (1994). Tobin's Q, corporate diversification and firm performance, Journal of Political Economy, 102, 1248-1280.

Levi, M.D. (1994). Exchange rates and the valuation of firms, In Amihud, Y., Levich, R.M. (Eds.), Exchange Rates and Corporate Performance. Irwin, New York, 37-48.

Magee, S. (2009). Foreign currency hedging and firm value: a dynamic panel approach (February 15, 2009). Available at SSRN: http://ssrn.com/abstract=1150471

Marston, R.C. (2001). The effects of industry structure on economic exposure. Journal of International Money and Finance, 20, 149-164.

Meade, J. (1951). The Theory of International Economic Policy, Vol.1, The Balance of Payments, London: Oxford University Press.

Mian, S. (1996). Evidence on corporate hedging policy. Journal of Financial and Quantitative Analysis, 419-439.

Miller, K.D., \& Reuer, J.J. (1998). Firm strategy and economic exposure to foreign exchange rate movements'. Journal of International Business Studies, 29, 493-514.

Muller, A., \& Verschoor W.F.C. (2006a), Asymmetric foreign exchange risk exposure: Evidence from U.S. multinational firms. Journal of Empirical Finance, 13, 495-518.

Muller, A., \& Verschoor W.F.C. (2006b), Foreign exchange risk exposure: Survey and suggestions. Journal of Multinational Financial Management, 16, 385-410.

Nance, D.R., Smith, C.W., \& Smithson, C.W. (1993). On the determinants of corporate hedging. Journal of Finance,48, 267-284.

Nguyen, H., \& Faff, R. (2003). Can the use of foreign currency derivatives explain variations in foreign exchange exposure? Evidence from Australian companies. Journal of Multinational Financial Management, 13, 193-215.

Nguyen, H., Faff, R.W., \& Marshall, A.P. (2007). Exchange rate exposure, foreign currency derivatives and the introduction of the Euro: French evidence. International Review of Economics and Finance, 16, 563-577.

Nydahl S. (1999). Exchange rate exposure, foreign involvement and currency hedging of firms: Some Swedish evidence. European Financial Management, 5, 241-257.

Oh, S., \& Lee, H. (2004). Foreign exchange exposures and asymmetries of exchange rate: Korean economy is highly vulnerable to exchange rate variations. Journal of Financial Management and Analysis, 17, 8-21.

Pearce, I. F. (1961). The problem of the balance of payments. International Economic Review 2, 1-28. 
Peltzman, S. (1977). The gains and losses from industrial concentration. Journal of Law and Economics, 20, 229-263.

Petersen, M., (2009). Estimating standard errors in finance panel data sets: Comparing approaches. Review of Financial Studies, 22, 435-480.

Pramborg, B. 2005, Foreign exchange risk management by Swedish and Korean nonfinancial firms: A comparative survey. Pacific Basin Finance Journal, 13, 343-366.

Shapiro, A.C., 1975, Exchange rate changes, inflation and the value of multinational corporations. Journal of Finance, 30, 485-502.

Servaes, H. (1996). The value of diversification during the conglomerate merger wave, Journal of Finance, 51, 1201-1225.

Smith, C. W. J., \& Stulz, R. M. (1985). The Determinants of firms' hedging policies. Journal of Financial and Quantitative Analysis, 20, 391-405.

Stock, J., \& Yogo, M. (2005). Testing for weak instruments in linear IV regression, in J. Stock and D. Andrews (eds.), Identification and Inference for Econometric Models: A Festschrift in Honor of Thomas Rothenberg (Cambridge University Press: Cambridge), 80-108.

Tai, C. (2008). Asymmetric currency exposure and currency risk pricing. International Review of Financial Analysis, 17, 647-663.

Tsiang, S. C. (1961). The Role of money in trade balance stability: synthesis of the elasticity and absorption approaches. American Economic Review, 51, 912-936.

Tufano, P. (1998). Agency costs of corporate risk management. Financial Management, 27, 67-77.

Williamson, R.G. (2001). Exchange rate exposure and competition: Evidence from the automotive industry. Journal of Financial Economics, 59, 441-475.

Wong, F.M.H. (2000). The association between SFAS No.119 derivatives disclosures and the foreign exchange risk exposure of manufacturing firms. Journal of Accounting Research, 38, 387-417.

Wysocki, P. (1995). Determinants of foreign exchange derivatives use by US corporations: An empirical investigation. Working paper, Simon School of Business, University of Rochester. 


\section{Appendix}

The KM model involves rewriting equation (3) as:

$$
R_{i t}=\beta_{i, 0}+\beta_{i, m} R_{m, t}+\left(\beta_{i, u s}+\beta_{D, u s} D_{u s, t}\right) R_{u s, t}+\left(\beta_{i, r e s}+\beta_{D, r e s} D_{r e s, t}\right) R_{r e s, t}+\varepsilon_{i, t}
$$

where $\beta_{i, u s}=\beta_{i, u s}^{A p p}, \quad \beta_{D, u s}=\left(\beta_{i, u s}^{D e p}-\beta_{i, u s}^{A p p}\right)$ and $D_{u s, t}=1$ if $R_{u s, t}<0$ and 0 otherwise and $\beta_{i, r e s}=\beta_{i, r e s}^{A p p}, \beta_{D, r e s}=\left(\beta_{i, r e s}^{D e p}-\beta_{i, r e s}^{A p p}\right)$ and $D_{r e s, t}=1$ if $R_{r e s, t}<0$ and 0 otherwise. The test for asymmetry is equivalent to testing that $\beta_{D, u s d}\left(\beta_{D, \text { res }}\right)$ is statistically significant, irrespective of the sign of the coefficient. For a given value of the market portfolio, the response of $R_{i t}$ will be $\beta_{i, u s}\left(\beta_{i, r e s}\right)$ when $R_{u s}>0\left(R_{\text {res }}>0\right)$ and $\beta_{i, u s}+\beta_{D, u s_{x}}\left(\beta_{i, r e s}+\beta_{D, \text { res }_{x}}\right)$ when $R_{u s}<0$ $\left(R_{\text {res }}<0\right)$. 
Table 1. Sample description of FC derivatives use

\begin{tabular}{|l|c|c|c|c|}
\hline & 2002 & 2003 & 2004 & 2005 \\
\hline $\mathrm{N}^{\circ}$ of FC derivatives users & 70 & 96 & 81 & 88 \\
\hline $\mathrm{N}^{\circ}$ of non users & 141 & 115 & 130 & 123 \\
\hline $\mathrm{N}^{\circ}$ of firms & 211 & 211 & 211 & 211 \\
\hline
\end{tabular}

Table 2 Sample industry classification using Campbell (1996) classification

\begin{tabular}{|l|l|c|}
\hline Industry & SIC codes & Percentage of total \\
\hline Petroleum & 13,29 & 1.5 \\
Consumer durables & $25,30,36,37,50,55,57$ & 21 \\
Basic industry & $10,12,14,24,26,28,33$ & 12.5 \\
Food and tobacco & $1,2,9,20,21,54$ & 5 \\
Construction & $15,16,17,32,52$ & 3 \\
Capital goods & $34,35,38$ & 11 \\
Transportation & $40,41,42,44,45,47$ & 4.5 \\
Utilities & $46,48,49$ & 6.5 \\
Textiles and trade & $22,23,31,51,53,56,59$ & 8 \\
Services & $72,73,75,76,80,82,87,89$ & 21.5 \\
Leisure & $27,58,70,78,79$ & 5.5 \\
\hline Total & & 100 \\
\hline
\end{tabular}

Table 3 Sample Descriptive Statistics

\begin{tabular}{lrrrrr}
\hline Variables & Mean & Median & SD. & Min. & Max. \\
\hline TOBIN Q & 1.465 & 1.200 & 0.963 & 0.592 & 13.494 \\
DERIV & 0.088 & 0.016 & 0.310 & 0 & 6.007 \\
LEV & 0.254 & 0.256 & 0.159 & 0 & 1.185 \\
DY & 1.710 & 1.497 & 2.522 & 0 & 54.857 \\
QUICK & 1.071 & 0.878 & 0.884 & 0.124 & 10.337 \\
SIZE & 19.840 & 19.499 & 2.209 & 15.605 & 25.854 \\
PROF & 5.533 & 4.664 & 4.592 & 0.038 & 55.002 \\
FSTS & 0.471 & 0.489 & 0.266 & 0 & 1 \\
CAPEX & 5.108 & 3.916 & 5.487 & 0 & 65.082 \\
R(MSCI) & 0.001 & 0.002 & 0.019 & -0.062 & 0.096 \\
R(X) & 0.001 & 0.001 & 0.007 & -0.023 & 0.018 \\
\hline
\end{tabular}

This table reports summary statistics for firm characteristics, market returns and exchange rate returns from 2002 to 2005 for a sample of 211 French firms. TOBIN $Q$ is the ratio of market value of assets to the book value of assets, where the market value of assets is the book value of assets less the book value of equity plus the market value of equity. DERIV is defined as the notional amount of FCD divided by total assets. LEV is the ratio of Book value of long term debts to total assets. DY is the dividend per share divided by the share price. QUICK is measured as the ratio of cash plus marketable securities to short term liabilities. SIZE is the natural logarithm of the firm's total assets. PROF is the ratio of earnings before interest and taxes to total assets. CAPEX is the ratio of total capital expenditure to total assets. FSTS is the ratio of foreign sales to total sales. For all the above data are as of the end of fiscal year. R(MSCI) is the weekly return on the MSCI world index. $\mathrm{R}(\mathrm{X})$ is the weekly return on a trade-weighted exchange rate index, the Euro effective index. 
Table 4. Descriptive statistics of asymmetric foreign exchange exposures

\begin{tabular}{|l|c|c|c|c|c|c|c|c|}
\hline \multirow{2}{*}{} & \multicolumn{3}{|c|}{$\mathbf{2 0 0 2}$} & \multicolumn{3}{c|}{$\mathbf{2 0 0 3}$} \\
\cline { 2 - 11 } & $\beta_{i, u s}^{\text {App }}$ & $\beta_{i, u s}^{\text {Dep }}$ & $\beta_{i, \text { res }}^{\text {App }}$ & $\beta_{i, \text { res }}^{\text {Dep }}$ & $\beta_{i, u s}^{\text {App }}$ & $\beta_{i, u s}^{\text {Dep }}$ & $\beta_{i, \text { res }}^{\text {App }}$ & $\beta_{i, r e s}^{\text {Dep }}$ \\
\hline Median & 0.094 & 0.189 & -2.540 & 0.758 & 0.103 & -0.130 & -0.50 & -0.475 \\
\hline Mean & 0.069 & 0.216 & -2.718 & 1.062 & 0.145 & -0.034 & -0.161 & -0.319 \\
\hline S. D. & 1.861 & 2.308 & 8.757 & 7.789 & 1.321 & 1.563 & 6.076 & 4.648 \\
\hline No & 211 & 211 & 211 & 211 & 211 & 211 & 211 & 211 \\
\hline No. of sig. Cases & 19 & 21 & 30 & 24 & 27 & 30 & 26 & 31 \\
\hline $\begin{array}{l}\text { Total nbr of sig. } \\
\text { Cases }\end{array}$ & \multicolumn{3}{|c|}{94} & & & \multicolumn{3}{|c}{114} \\
\hline
\end{tabular}

\begin{tabular}{|l|c|c|c|c|c|c|c|c|}
\hline & \multicolumn{9}{|c|}{$\mathbf{2 0 0 4}$} & \multicolumn{3}{c|}{$\mathbf{2 0 0 5}$} \\
\cline { 2 - 10 } & $\beta_{i, u s}^{\text {App }}$ & $\beta_{i, u s}^{\text {Dep }}$ & $\beta_{i, \text { res }}^{\text {App }}$ & $\beta_{i, r e s}^{\text {Dep }}$ & $\beta_{i, u s}^{\text {App }}$ & $\beta_{i, u s}^{\text {Dep }}$ & $\beta_{i, \text { res }}^{\text {App }}$ & $\beta_{i, \text { res }}^{\text {Dep }}$ \\
\hline Median & -0.197 & -0.108 & -0.775 & 0.182 & -0.248 & -0.154 & -0.194 & 0.077 \\
\hline Mean & -0.273 & 0.013 & -1.020 & 0.528 & -0.253 & -0.125 & -0.208 & -0.195 \\
\hline S. D. & 2.055 & 1.030 & 3.602 & 4.006 & 1.182 & 0.954 & 5.431 & 6.161 \\
\hline N & 211 & 211 & 211 & 211 & 211 & 211 & 211 & 211 \\
\hline Nb. of sig. Cases & 26 & 31 & 43 & 29 & 27 & 28 & 38 & 37 \\
\hline $\begin{array}{l}\text { Total nb. of sig. } \\
\text { cases }\end{array}$ \\
\hline $\begin{array}{l}\text { Total nb. of sig. } \\
\text { cases 2002-2005 } \\
\text { Number of firms }\end{array}$
\end{tabular}

The above table reports descriptive statistics of the FC exchange exposures estimated from equation (2) for each fiscal year and for each firm using weekly returns. The significance level is $5 \%$.

Table 5. Number of asymmetric exposure coefficients 2002-2005 (5\% level of significance)

\begin{tabular}{|l|c|c|c|c|c|}
\hline & 2002 & 2003 & 2004 & 2005 & Total \\
\hline$\beta_{i D, \text { usd }}$ & 18 & 36 & 26 & 27 & $\mathbf{1 0 7}$ \\
\hline$\beta_{i D, \text { res }}$ & 29 & 28 & 38 & 40 & $\mathbf{1 3 5}$ \\
\hline Total & $\mathbf{4 7}$ & $\mathbf{6 4}$ & $\mathbf{6 4}$ & $\mathbf{6 7}$ & $\mathbf{2 4 2}$ \\
\hline
\end{tabular}


Table 6 Exchange rate exposure and derivatives use

\begin{tabular}{|c|c|c|c|c|c|c|c|c|}
\hline & \multicolumn{4}{|c|}{ Whole sample } & \multicolumn{4}{|c|}{ Asymmetric sub-sample } \\
\hline & (2) & (3) & (4) & (5) & (6) & (7) & (8) & (9) \\
\hline & (eq.3a) & (eq.3b) & (eq.3c) & (eq.3d) & (eq.3a) & (eq.3b) & (eq.3c) & (eq.3d) \\
\hline & $\left|\beta_{i, u s}^{A p p}\right|$ & $\left|\beta_{i, u s}^{\text {Dep }}\right|$ & $\left|\beta_{i, r e s}^{\text {App }}\right|$ & $\left|\beta_{i, r e s}^{\text {Dep }}\right|$ & $\left|\beta_{i, u s}^{A p p}\right|$ & $\left|\beta_{i, u s}^{\text {Dep }}\right|$ & $\left|\beta_{i, r e s}^{\text {App }}\right|$ & $\left|\beta_{i, r e s}^{\text {Dep }}\right|$ \\
\hline \multirow{2}{*}{$\left(\alpha_{2}\right)$ DERIV x $u s d_{+}^{A p p}$} & $-2.678^{\mathrm{a}}$ & & & & 1.352 & & & \\
\hline & $(-2.32)$ & & & & $(1.21)$ & & & \\
\hline \multirow[t]{2}{*}{$\left(\alpha_{3}\right)$ DERIV x $u s d_{-}^{A p p}$} & $-2.602^{\mathrm{a}}$ & & & & -0.047 & & & \\
\hline & $(-2.21)$ & & & & 1.352 & & & \\
\hline$\left(\alpha_{7}\right)$ DERIV x $u s d_{+}^{D e p}$ & & -1.736 & & & & 0.720 & & \\
\hline \multirow[t]{2}{*}{$\left(\alpha_{8}\right)$ DERIV x $u s d_{-}^{D e p}$} & & $\begin{array}{l}(-1.55) \\
-1.666\end{array}$ & & & & $\begin{array}{l}(0.48) \\
2.792^{b}\end{array}$ & & \\
\hline & & $(-1.53)$ & & & & (1.68) & & \\
\hline \multirow[t]{2}{*}{$\left(\alpha_{12}\right)$ DERIV x resd $d_{+}^{A p p}$} & & & $-11.739^{\mathrm{a}}$ & & & & -4.904 & \\
\hline & & & $\begin{array}{l}(-3.24) \\
-9.975^{a}\end{array}$ & & & & $\begin{array}{c}(-0.40) \\
0.240\end{array}$ & \\
\hline$\left(\alpha_{13}\right)$ DERIV x $r e s d_{-}^{A p p}$ & & & $(-2.97)$ & & & & $(0.04)$ & \\
\hline \multirow[t]{2}{*}{$\left(\alpha_{17}\right)$ DERIV x $r e s d_{+}^{\text {Dep }}$} & & & & $-12.921^{\mathrm{a}}$ & & & & -1.420 \\
\hline & & & & $(-3.35)$ & & & & $(-0.29)$ \\
\hline \multirow[t]{2}{*}{$\left(\alpha_{18}\right)$ DERIV x $r e s d_{-}^{\text {Dep }}$} & & & & $-10.365^{\mathrm{a}}$ & & & & -5.248 \\
\hline & & & & $(-2.82)$ & & & & $(-0.69)$ \\
\hline \multirow[t]{2}{*}{ SIZE } & 0.006 & -0.026 & -0.019 & -0.154 & 0.018 & -0.078 & 0.222 & 0.585 \\
\hline & $(0.18)$ & $(-0.88)$ & $(-0.16)$ & $(-1.15)$ & $(0.23)$ & $(-0.87)$ & $(0.38)$ & (1.38) \\
\hline \multirow[t]{2}{*}{ FSTS } & 0.012 & 0.312 & 1.205 & 1.247 & -1.023 & -0.212 & -0.905 & -3.380 \\
\hline & $(0.06)$ & (1.47) & (1.59) & (1.48) & $(-1.12)$ & $(-0.32)$ & $(-0.27)$ & $(-1.36)$ \\
\hline \multirow[t]{2}{*}{ Constant } & 0.720 & 0.892 & 4.603 & $8.469^{\mathrm{a}}$ & 1.953 & $3.627^{\mathrm{b}}$ & 7.157 & 0.939 \\
\hline & $(1.00)$ & $(1.39)$ & (1.35) & (2.38) & (1.04) & (1.90) & $(0.66)$ & $(0.12)$ \\
\hline Industry dummies & Yes & Yes & Yes & Yes & Yes & Yes & Yes & Yes \\
\hline Year dummies & Yes & Yes & Yes & Yes & Yes & Yes & Yes & Yes \\
\hline $\mathrm{N}$ & 517 & 517 & 517 & 517 & 66 & 66 & 75 & 75 \\
\hline Hausman-test $\chi^{2}(1)$ & $5.81^{\mathrm{a}}$ & $5.64^{\mathrm{a}}$ & $4.20^{\mathrm{a}}$ & $4.13^{\mathrm{a}}$ & $5.95^{\mathrm{a}}$ & $6.04^{\mathrm{a}}$ & $4.73^{\mathrm{a}}$ & $5.11^{\mathrm{a}}$ \\
\hline Anderson-Canon LM test & $229.37^{\mathrm{a}}$ & $228.31^{\mathrm{a}}$ & $118.19^{\mathrm{a}}$ & $117.14^{\mathrm{a}}$ & $229.37^{\mathrm{a}}$ & $226.87^{\mathrm{a}}$ & $117.18^{\mathrm{a}}$ & $116.18^{\mathrm{a}}$ \\
\hline Cragg-Donald F-test & $103.24^{\mathrm{a}}$ & $103.69^{\mathrm{a}}$ & $110.56^{\mathrm{a}}$ & $108.09^{\mathrm{a}}$ & $104.28^{\mathrm{a}}$ & $103.81^{\mathrm{a}}$ & $111.06^{\mathrm{a}}$ & $108.11^{\mathrm{a}}$ \\
\hline Wald-test & 0.02 & 0.19 & 0.21 & 0.15 & 0.74 & 1.14 & 0.16 & 0.26 \\
\hline
\end{tabular}

We use cross-sectional time series data for estimating the system of equations (3a, 3b, 3c and 3d). The dependent variables are the absolute values of FC exposures obtained from the estimation of equation 2. Columns 2 to 5 include all firms in the sample, where data on FC derivatives use and control variables is available. Columns 6 and 7 (columns 8 and 9) include only those firms that have significant asymmetric exposures to USD (RES). The estimator is 3SIS. DERIV, the notional amount of FC derivatives use divided by total assets, is being instrumented. The instruments are CAPEX, the ratio of total capital expenditure to total assets; DY, the dividend per share divided by the share price; LEV, the ratio of Book value of long term debts to total assets. $u s d_{+}{ }^{\text {App }}, u_{s} d_{-}^{\text {App }}$, usd ${ }_{+}{ }^{\text {Dep }}$, $u s d_{-}^{D e p}$, $\operatorname{res}_{+}{ }^{A p p}, \operatorname{resd}_{-}^{A p p}, \operatorname{resd}_{+}{ }^{D e p}, \operatorname{resd}_{-}{ }^{D e p}$ are dummy variables. $u s d_{+}{ }^{A p p},\left(u s d_{-}^{A p p}\right)$ takes the value 1 if $\beta_{i, u s}^{A p p}$ is positive (negative) and the Euro appreciates with respect to US Dollar. $u s d_{+}^{D e p}\left(u s d_{-}^{D e p}\right)$ takes the value 1 if $\beta_{i, u s}^{D e p}$ is positive (negative) and the Euro depreciates with respect to US Dollar. $R e s d_{+}^{A p p}$, $\left(r e s d_{-}^{A p p}\right.$ ) takes the value 1 if $\beta_{i, \text { res }}^{A p p}$ is positive (negative) and the Euro appreciates with respect to other currencies. resd $_{+}{ }^{\text {Dep }}$, resd ${ }_{-}^{\text {Dep }}$ takes the value 1 if $\beta_{i, r e s}^{\text {Dep }}$ is positive (negative) and the Euro depreciates with respect to other currencies. SIZE is the natural logarithm of the firm's total assets. FSTS is the ratio of foreign sales to total sales. Hausman test is a test for endogeneity bias. The null hypothesis of the Anderson-Canon test is underidentification. The Cragg-Donald F-test tests for weak identification (10\% critical value of Stock-Yogo weak ID test is 19.93). Wald-test is the test for difference between the interacted DERIV coefficients. $t$ statistics are in parentheses. Subscripts a and b indicate significance at the $5 \%$ level and at the $10 \%$ level respectively. 
Table 7 Exchange rate exposure and individual derivatives product

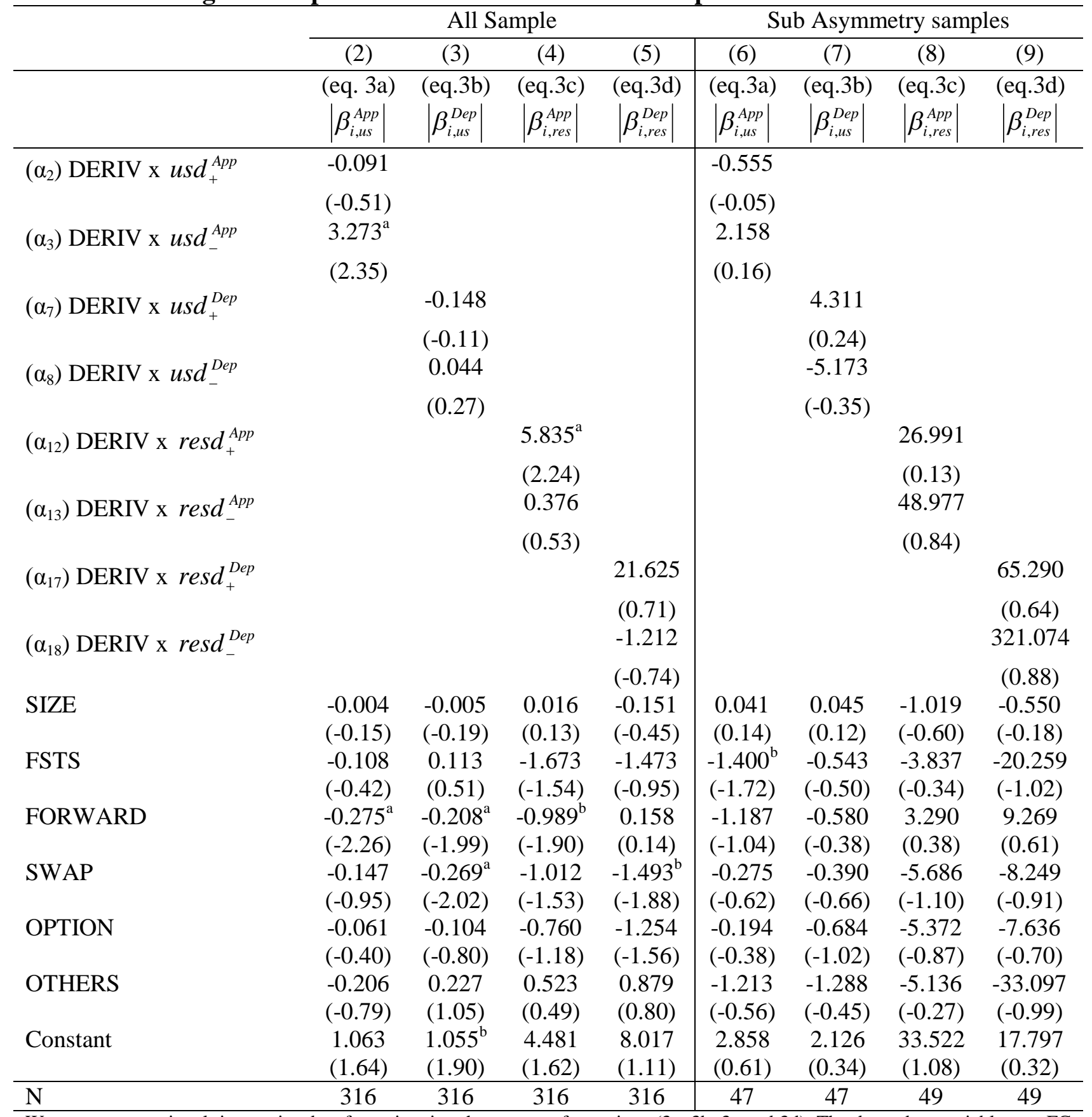

We use cross-sectional time series data for estimating the system of equations (3a, 3b, 3c and 3d). The dependent variables are FC exposures obtained from the estimation of equation 2. Columns 2 to 5 include all firms in the sample, where data on FC derivatives use and control variables is available. Columns 6 and 7 (columns 8 and 9) include only those firms that have significant asymmetric exposures to USD (RES). The estimator is 3SIS. FORWARD takes the value of 1 if the firm uses forward contracts and 0 otherwise, SWAP takes the value of 1 if the firm uses swaps and 0 otherwise, OPTION takes the value of 1 if the firm uses vanilla options and 0 otherwise and OTHERS takes the value of 1 if the firm uses another type of derivative, such as exotic options, and 0 otherwise. For definition of the other explanatory variables see Table 6. $t$ statistics are in parentheses. Subscripts a and $\mathrm{b}$ indicate significance at the $5 \%$ level and at the $10 \%$ level respectively. 
Table 8 Firm value and FC derivatives use

\begin{tabular}{|c|c|c|c|c|c|c|c|c|c|c|}
\hline & \multicolumn{5}{|c|}{ PANEL A } & \multicolumn{5}{|c|}{ PANEL B } \\
\hline & (2) & (3) & (4) & (5) & (6) & (7) & (8) & (9) & (10) & (11) \\
\hline \multirow[t]{2}{*}{ DERIV } & 0.097 & -0.217 & -0.275 & -0.179 & 0.089 & 0.002 & -0.098 & -0.093 & -0.448 & -0.005 \\
\hline & (1.32) & $(-1.01)$ & $(-0.98)$ & $(-0.55)$ & (1.39) & $(0.13)$ & $(-0.35)$ & $(-0.26)$ & $(-0.78)$ & $(-0.28)$ \\
\hline \multirow[t]{2}{*}{ SYMMETRIC } & & & & & & 0.044 & 0.106 & 0.147 & 0.081 & 0.026 \\
\hline & & & & & & (1.01) & $(1.24)$ & (1.18) & $(0.55)$ & $(0.52)$ \\
\hline \multirow[t]{2}{*}{ ASYMMETRIC } & & & & & & 0.101 & 0.145 & 0.137 & 0.346 & 0.054 \\
\hline & & & & & & (1.11) & (1.20) & $(0.83)$ & $(1.45)$ & $(0.46)$ \\
\hline \multirow[t]{2}{*}{ BOTH } & & & & & & -0.005 & -0.035 & -0.048 & -0.160 & 0.004 \\
\hline & & & & & & $(-0.10)$ & $(-0.32)$ & $(-0.32)$ & $(-0.72)$ & $(0.06)$ \\
\hline \multirow[t]{2}{*}{ CAPEX } & 0.0002 & 0.009 & $0.027^{\mathrm{a}}$ & -0.002 & -0.003 & -0.0003 & 0.007 & $0.037^{\mathrm{b}}$ & -0.008 & -0.005 \\
\hline & $(0.07)$ & $(1.35)$ & (2.17) & $(-0.40)$ & $(-0.80)$ & $(-0.08)$ & $(0.64)$ & (1.77) & $(-0.61)$ & $(-0.93)$ \\
\hline \multirow[t]{2}{*}{ DY } & 0.00006 & $0.011^{\mathrm{a}}$ & -0.007 & $0.009^{b}$ & $-0.046^{\mathrm{a}}$ & 0.004 & $0.008^{\mathrm{b}}$ & 0.049 & 0.003 & $-0.054^{\mathrm{a}}$ \\
\hline & $(0.01)$ & $(2.43)$ & $(-0.19)$ & (1.67) & $(-2.86)$ & $(0.48)$ & $(1.74)$ & $(0.59)$ & $(0.24)$ & $(-2.89)$ \\
\hline \multirow[t]{2}{*}{ QUICK } & $0.076^{\mathrm{a}}$ & 0.115 & 0.248 & 0.092 & $0.069^{\mathrm{a}}$ & $0.077^{\mathrm{b}}$ & 0.073 & 0.244 & 0.036 & 0.044 \\
\hline & (2.49) & (1.42) & (1.56) & (1.09) & $(2.28)$ & (1.73) & $(0.74)$ & $(1.22)$ & $(0.28)$ & $(0.94)$ \\
\hline \multirow[t]{2}{*}{ PROF } & $0.010^{\mathrm{a}}$ & 0.002 & -0.016 & 0.003 & $0.014^{\mathrm{a}}$ & $0.014^{\mathrm{a}}$ & 0.0004 & -0.026 & 0.0002 & $0.021^{\mathrm{a}}$ \\
\hline & $(2.18)$ & $(0.54)$ & $(-1.65)$ & $(0.55)$ & $(2.38)$ & $(2.20)$ & $(0.12)$ & $(-1.58)$ & $(0.04)$ & (2.74) \\
\hline \multirow[t]{2}{*}{ SIZE } & $-0.024^{a}$ & $-0.029^{b}$ & 0.008 & $-0.041^{b}$ & -0.006 & $-0.023^{a}$ & $-0.043^{a}$ & -0.021 & -0.041 & -0.005 \\
\hline & $(-2.77)$ & $(-1.96)$ & $(0.24)$ & $(-1.94)$ & $(-0.62)$ & $(-2.44)$ & $(-2.32)$ & $(-0.50)$ & $(-0.96)$ & $(-0.47)$ \\
\hline \multirow[t]{2}{*}{ LEV } & -0.197 & $-0.428^{a}$ & $-0.704^{a}$ & -0.377 & -0.216 & $-0.281^{b}$ & -0.201 & -0.389 & 0.134 & $-0.469^{a}$ \\
\hline & $(-1.37)$ & $(-2.05)$ & $(-2.65)$ & $(-0.99)$ & $(-1.20)$ & $(-1.79)$ & $(-0.68)$ & $(-0.89)$ & $(0.20)$ & $(-2.41)$ \\
\hline \multirow[t]{2}{*}{ Constant } & $0.640^{\mathrm{a}}$ & $0.817^{\mathrm{a}}$ & 0.002 & $1.121^{\mathrm{a}}$ & $0.380^{\mathrm{b}}$ & $0.624^{\mathrm{a}}$ & $1.092^{\mathrm{a}}$ & 0.321 & 1.251 & 0.443 \\
\hline & $(3.56)$ & $(2.44)$ & $(0.00)$ & $(2.32)$ & (1.76) & $(2.87)$ & $(2.51)$ & $(0.36)$ & $(1.28)$ & (1.62) \\
\hline Ind. $d$ & Yes & Yes & Yes & Yes & Yes & Yes & Yes & Yes & Yes & Yes \\
\hline Year dummies & Yes & Yes & Yes & Yes & Yes & Yes & Yes & Yes & Yes & Yes \\
\hline $\mathrm{N}$ & 523 & 138 & 71 & 80 & 385 & 354 & 97 & 50 & 54 & 257 \\
\hline$R^{2}$ & 0.21 & 0.33 & 0.45 & 0.34 & 0.26 & 0.23 & 0.39 & 0.55 & 0.47 & 0.30 \\
\hline \multicolumn{11}{|c|}{$\begin{array}{l}\text { We use cross-sectional time series data for estimating the above models. The dependent variable is the natural logarithm of Tobin's Q. } \\
\text { Columns } 2 \text { and } 7 \text { include all firms in the sample, where data on explanatory variables is available. Columns } 3 \text { and } 8 \text { include only those firms } \\
\text { that have significant asymmetric exposures to either USD or RES. Columns } 4 \text { and } 9 \text { (columns } 5 \text { and 10) include only those firms that have } \\
\text { significant asymmetric exposures to USD (RES). Columns } 6 \text { and } 11 \text { include only those firms that have non significant asymmetric exposures. } \\
\text { DERIV, the notional amount of FC derivatives use divided by total assets, is being instrumented. The instruments are CAPEX, the ratio of } \\
\text { total capital expenditure to total assets; DY, the dividend per share divided by the share price; LEV, the ratio of Book value of long term } \\
\text { debts to total assets. QUICK is the ratio of cash plus marketable securities to short term liabilities. PROF is the ratio of earnings before } \\
\text { interest and taxes to total assets. SIZE is the natural logarithm of the firm's total assets. LEV is the ratio of Book value of long term debts to } \\
\text { total assets. The models are estimated using ordinary least squares regression. The coefficients' standard errors are adjusted for the effects of } \\
\text { non-independence by clustering on each firm (Petersen 2009). } t \text { statistics in parentheses } t \text {. Subscripts a and b indicate significance at the } 5 \% \\
\text { level and at the } 10 \% \text { level respectively. }\end{array}$} \\
\hline
\end{tabular}

